\title{
Hukum Dan Kekerasan Di Sekolah: Optimalisasi Peran Konselor Sekolah
}

\author{
Nurochim Nurochim ${ }^{1}$, Siti Ngaisah ${ }^{2 *}$ \\ ${ }^{I}$ Fakultas Ilmu Tarbiyah dan Keguruan UIN Syarif Hidayatullah, Jakarta, Indonesia \\ ${ }^{2}$ Departemen Penelitian dan Pengembangan Masyarakat CIC Riset dan Konsultan Sosial, Depok, \\ Indonesia \\ *E-mail: sitingaisahcic@gmail.com
}

\begin{tabular}{l}
\hline Info Artikel \\
\hline \\
Keywords: \\
Violence; School; \\
Law; Counselor. \\
\\
Kata Kunci: \\
Kekerasan; Sekolah; \\
Hukum; Konselor.
\end{tabular}

\begin{abstract}
Violence in the school environment is still a problem that requires multi-sectoral solutions. The school is an organization as a place to gather for a long time. Interactions in schools are multistrata interactions such as differences in the social backgrounds of students, teachers, and education personnel. The method used in this article is literature review. The results of the study in this study are school counselors have an important role in developing social attitudes of school residents with programmatic counseling activities. The counseling program is implemented to provide rights and obligations for school residents. By having a social attitude, conflicts between school members can be prevented. Counseling activities are organized as preventive and curative activities from violence in schools.
\end{abstract}

\begin{tabular}{l}
\hline Abstrak \\
Kekerasan di lingkungan sekolah masih menjadi masalah yang \\
membutuhkan solusi multi-sektoral. Sekolah adalah organisasi \\
sebagai tempat berkumpul untuk waktu yang lama. Interaksi di \\
sekolah adalah interaksi multistrata seperti perbedaan latar belakang \\
sosial siswa, guru, dan tenaga kependidikan. Metode yang digunakan \\
dalam artikel ini adalah tinjauan literatur. Hasil penelitian dalam \\
penelitian ini adalah konselor sekolah memiliki peran penting dalam \\
mengembangkan sikap sosial warga sekolah dengan kegiatan \\
konseling terprogram. Program konseling dilaksanakan untuk \\
memberikan hak dan kewajiban bagi penghuni sekolah, dengan \\
memiliki sikap sosial, konflik antar anggota sekolah dapat dicegah. \\
Kegiatan konseling diselenggarakan sebagai kegiatan preventif dan \\
kuratif dari kekerasan di sekolah.
\end{tabular}

\section{A. PENDAHULUAN}

Pelaksanaan pendidikan penting mengacu pada unsur-unsur administrasi pendidikan, salah satunya adalah administrasi peserta didik. ${ }^{1}$ Dalam Undang-Undang Sistem Pendidikan Nasional, dinyatakan bahwa Pendidikan adalah usaha sadar dan terencana untuk mewujudkan suasana belajar dan proses pembelajaran agar peserta didik

${ }^{1}$ Mehta, D. (2009). Educational administration. New Delhi: A.P.H. Pub. Corp. 
secara aktif mengembangkan potensi dirinya untuk memiliki kekuatan spiritual keagamaan, pengendalian diri, kepribadian, kecerdasan, akhlak mulia, serta keterampilan yang diperlukan dirinya, masyarakat, bangsa dan Negara, ${ }^{2}$ dalam undang-undang tersebut dinyatakan bahwa pendidikan merupakan sarana yang sangat penting dalam mengembangakan kecerdasan sosial, spiritual, dan kecerdasan. Pengendalian diri juga ditekankan dalam proses pendidikan. Namun demikian permasalahan di lingkungan sekolah, yakni kekerasan masih marak menjadi pemberitaan.

Tindak kekerasan di lingkungan sekolah bisa dialamai oleh siswa, guru, dan tenaga kependidikan, yang pelakunya juga di lingkup tersebut. Peristiwa murid mencekik guru di Gresik, Jawa Timur, menjadi sangat viral di media sosial. Meskipun kedua belah pihak sudah didamaikan dan sang murid sudah meminta maaf secara langsung kepada sang guru, kejadian ini terlanjur mencoreng wajah pendidikan di Tanah Air. ${ }^{3}$

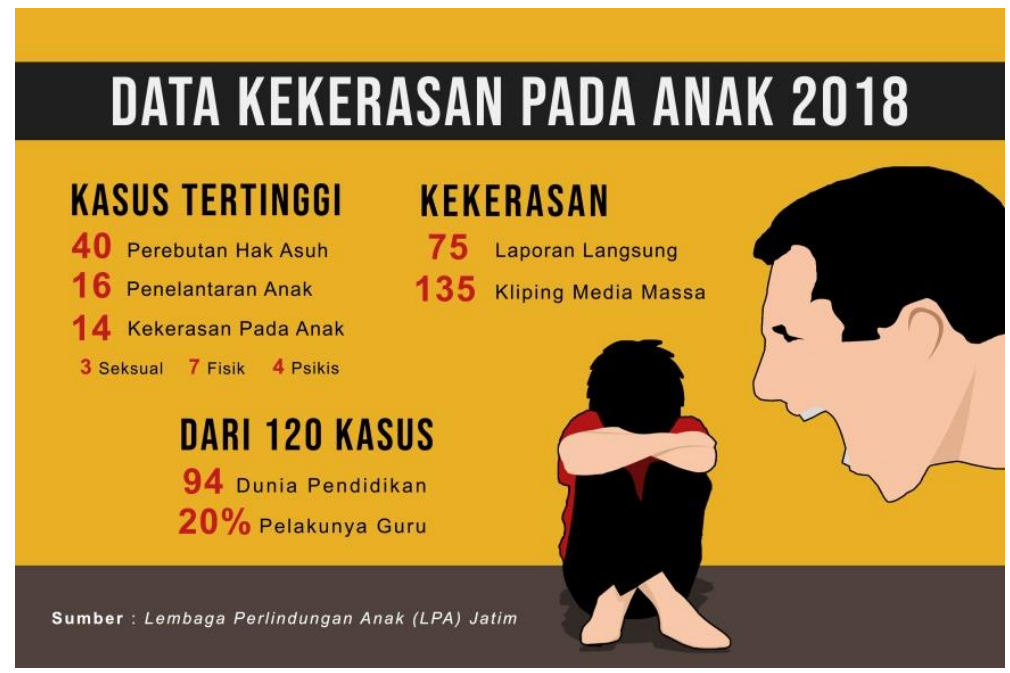

Data kekerasan pada anak dari Lembaga Perlindungan Anak Provinsi Jawa Timur menunjukkan bahwa pada tahun 2018 dari 120 kasus kekerasan pada anak, terjadi di dunia pendidikan, artinya lebih dari setengah kasus, dan lebih banyak pelakunya adalah guru.

Kasus penganiayaan di sekolah dialami seorang guru honorer si SMA Negeri 1 Torjun, Sampang, Madura, Jawa Timur, dilaporkan meninggal dunia. Guru bidang kesenian meninggal akibat mati batang otak (MBO) setelah dipukul oleh siswanya yang berinisial HI. ${ }^{4}$ Pada umumnya guru kesenian memiliki kedekatan karena memiliki kesamaan hobi di bidang seni. Terlebih guru dan siswa tersebut sama-sama generasi milenial.

Kekerasan di sekolah yang diduga dilakukan oleh guru kepada siswa, juga marak dan viral di media sosial. ${ }^{5}$ Siswa yang belum membayar SPP juga diberikan hukuman

2 Undang-Undang Nomor 20 tahun 2003. Undang-Undang Republik Indonesia Nomor 20 Tahun 2003 Tentang Sistem Pendidikan Nasional. 2003

3 Republika. "Kasus Kekerasan Terhadap Guru Kesalahan Sistemis" | Republika Online [Internet]. Republika. 2019 [cited 2019 Dec 29]. Available from: https://republika.co.id/berita/pmuwyp291/kasuskekerasan-terhadap-guru-kesalahan-sistemis

4 Republika. Pendidikan Karakter Harus Diperkuat di Sekolah | Republika Online [Internet]. Republika. 2018 [cited 2019 Dec 29]. Available from: https://republika.co.id/berita/p3kaqz284/pendidikankarakter-harus-diperkuat-di-sekolah

5 Republika. Kekerasan Jadi Tantangan Pendidikan di Indonesia | Republika Online [Internet]. $\begin{array}{llllll}\text { Republika. } 2017 \quad \text { [cited } 2019 & \text { Dec 29]. } & \text { p. } 1 . & \text { Available from: }\end{array}$ 
oleh pihak sekolah. ${ }^{6}$ Tidak hanya di sekolah nasional, sekolah internasionalpun tidak luput dari tindak kekerasan. ${ }^{7}$ Hal tersebut menunjukkan bahwa kekerasan dalam dunia pendidikan masih menjadi pekerjaan rumah yang serius.

Kekerasan yang dialami oleh siswa dari siswa terjadi di salah satu SMK Negeri di Rempoa Tangerang Selatan. Para korban yang terdiri dari 13 siswa mengaku ditampari satu-persatu, bahkan hingga dipaksa berduel satu lawan satu. ${ }^{8}$

Dalam Peraturan Menteri Pendidikan dan Kebudayaan (Permendikbud) nomor 82 tahun 2015 ditulis bahwa tindak kekerasan yang dilakukan di lingkungan satuan pendidikan maupun antar satuan pendidikan, dapat mengarah kepada suatu tindak kriminal dan menimbulkan trauma bagi peserta didik. ${ }^{9}$ Trauma dan tindak kriminal menyebabkan kegiatan belajar terganggu, sehingga upaya dalam mewujudkan sumber daya manusa yang berkualitas juga menjadi terhambat.

Solusi akan kekerasan anak dan perempuan salah satunya adalah upaya meningkatkan kesadaran masyarakat akan pentingnya usaha menyelesaikan terjadinya kekerasan terhadap perempuan dan anak, dalam konteks individual, sosial maupun institusional. ${ }^{10}$ Konteks lembaga pendidikan khususnya. Dengan kesadaran masyarakat yang meningkat diharapkan dapat memberikan pemahaman akan kekerasan dan bagaimana solusinya, sehingga hak dan kewajiban masing-masing akan terjaga. Lebih lanjut konseling korban kekerasan menjadi solusi kasus kekerasan, namun demikian konseling juga memiliki fungsi dalam mencegah terjadinya kekerasan. Konseling juga berfungsi sebagai sarana kampanye dalam menanggulangi tindak kekerasan.

Konteks lain adalah kerjasama antara sekolah dengan orang tua, terutama ibu, dalam rangka membimbing dan mendidik anak-anak secara bekerjasama, oleh sebab itu sangat diperlukan waktu yang cukup dari seorang ibu kepada anak-anaknya. ${ }^{11}$ Konseling pendidikan juga sangat penting memberikan pemahaman akan kekerasan dan interaksi di sekolah.

Hubungan kerjasama antara pihak-pihak yang berkesinambungan ${ }^{12}$, maka akan diperoleh solusi akan maraknya tindak kekerjasan. Pihak-pihak yang bekerjasama adalah para stakeholder pendidikan, seperti komite sekolah, orang tua, masyarakat lingkungan, dinas pendidikan lokal dan nasional. Pemahaman akan payung hukum penyelesaian

https://republika.co.id/berita/oz3e86368/kekerasan-jadi-tantangan-pendidikan-di-indonesia

${ }^{6}$ Liputan Khusus Koran Sindo. Belum Bayar SPP, Bocah 10 Tahun Dihukum Push-up 100 Kali

[Internet]. Sindo News. 2019 [cited 2019 Dec 29]. p. 1. Available from: https://metro.sindonews.com/read/1374283/170/belum-bayar-spp-bocah-10-tahun-dihukum-push-up-100kali-1548685354

7 Liputan Khusus Koran Sindo. Diduga Aniaya Murid, Guru Sekolah Internasional Dilaporkan ke...

[Internet]. Sindo News. 2019 [cited 2019 Dec 29]. p. 1. Available from: https://metro.sindonews.com/read/1400581/170/diduga-aniaya-murid-guru-sekolah-internasionaldilaporkan-ke-polisi-1556722061

8 Liputan Khusus Koran Sindo. Di-bully Senior, 13 Siswi di Tangerang Selatan Ditampar hingga Dipaksa... [Internet]. Sindo News. 2019 [cited 2019 Dec 29]. p. 1. Available from: https://metro.sindonews.com/read/1426171/170/di-bully-senior-13-siswi-di-tangsel-ditampar-hinggadipaksa-berduel-1564733037

9 Kemendikbud. Peraturan Menteri Pendidikan Dan Kebudayaan Republik Indonesia Nomor 82 Tahun 2015 Tentang Pencegahan Dan Penanggulangan Tindak Kekerasan Di Lingkungan Satuan Pendidikan.

10 Pasalbessy, J.D. (2010). "Dampak Tindak Kekerasan Terhadap Perempuan Dan Anak Serta Solusinya”. SASI. $16(3):$ h. 8-13.

11 Latuny, M. (2012). "Peran Ganda Perempuan Dalam Keluarga”. SASI. 18 (1) : 13-20.

12 Hattu, J. (2014). “Kebijakan Hukum Pidana Dalam Penanggulangan Kejahatan Anak”. SASI. 20 (2) : h. 47-52. 
tindak kekerasan di sekolah oleh para guru, wajib pula untuk dilaksanakan. ${ }^{13}$

\section{B. METODE PENELITIAN}

Metode yuridis normatif digunakan dalam artikel ini. Pendekatan ini digunakan dengan tujuan menemukan bahan kepustakaan atau data sekunder yang dapat menjadi referensi penelitian hukum di lingkungan sekolah. Hasil penelitian dan data sekunder yang berkaitan dengan kekerasan di sekolah. Artikel ini dibahas secara deskriptif analitis mengenai implementasi dan menguji pelaksanaan ketentuan normatif di dalam praktik. Deskriptif berarti bersifat menggambarkan kondisi pelaksanaan di sekolah. Suatu penelitian deskriptif dimaksudkan untuk memberikan data yang detail dan komprehensif tentang manusia, keadaan atau gejala-gejala lainnya.

\section{PEMBAHASAN}

\section{Kekerasan Di Lingkungan Sekolah}

Lingkungan satuan pendidikan yang bebas dari tindak kekerasan dapat meningkatkan mutu pendidikan mulai dari satuan pendidikan yang paling rendah. Satuan pendidikan yang aman, nyaman, dan menyenangkan adalah dambaan dari lingkungan sekolah yang sesungguhnya. Keamanan dan kenyamanan menjadi jaminan ketika orang tua bekerjasama dengan sekolah dalam mendidik anak-anak. Yang sering diabaikan adalah POS (Prosedur Operasi Standar) yang tertulis dalam menyelesaikan tindak kekerasan. POS tersebut wajib disosialisasikan secara terus menerus. ${ }^{14}$

Kekerasan di lingkungan pendidikan oleh guru biasasnya berkaitan dengan proses pendisiplinan siswa. ${ }^{15}$ Kekerasan yang dilakukan oleh sesama siswa biasanya berkaitan dengan saling singgung antar siswa. Kekerasan yang dilakukan oleh siswa kepada guru, berkaitan dengan karakter siswa yang kurang baik. Namun demikian ada juga kekerasan yang dilakukan oleh orang tua kepada siswa, karena alasan dendam karena anaknya pernah dianiaya. Kekerasan tersebut tidak hanya kekerasan secara fisik, namun juga kekerasan secara psikis berupa ancaman, intimidasi, olok-olok, penghinaan, yang menyebabkan rasa trauma pada korban.

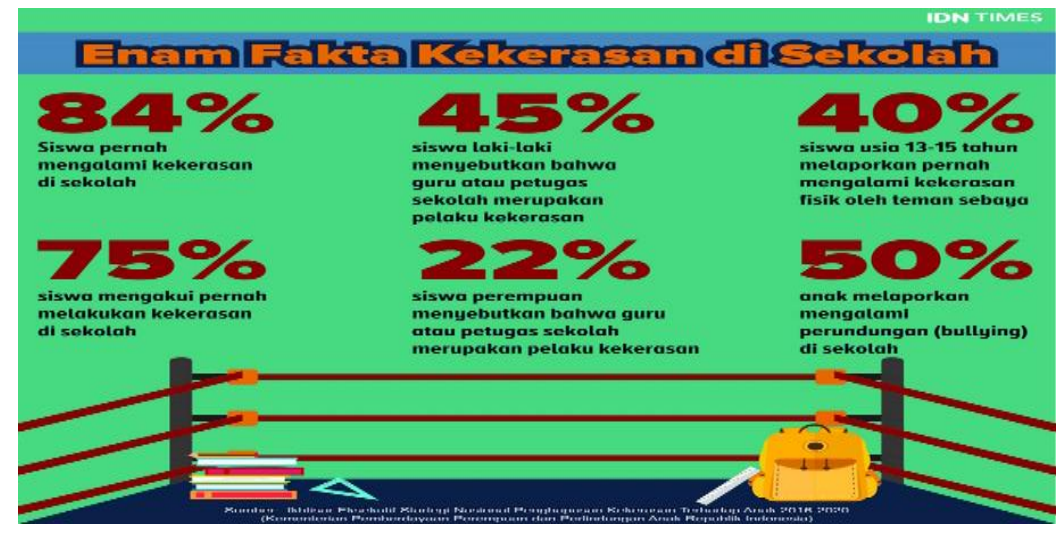

13 Republika. KPAI Dorong Kemendikbud Tingkatkan Keamanan di Sekolah | Republika Online [Internet]. Republika. 2019 [cited 2019 Dec 29]. h. 1. Available from: https://republika.co.id/berita/q35byn368/kpai-dorong-kemendikbud-tingkatkan-keamanan-di-sekolah

14 Republika. Tindak Kekerasan di Sekolah dan Efekivitas Permendikbud 82 | Republika Online [Internet]. Republika. 2019 [cited 2019 Dec 29]. p. 1. Available from: https://republika.co.id/berita/q1izh6349/tindak-kekerasan-di-sekolah-dan-efekivitas-permendikbud-82.

15 Bezem J, Heinen D, Reis R, Buitendijk SE, Numans ME, Kocken PL. (2017). “ Improving access to school health services as perceived by school professionals". BMC Health Serv Res. 17 (743) : h. 1-8. 
Berdasarkan infografis dari Kementerian Pemberdayaan Perempuan dan Perlindungan Anak di atas, menunjukkan bahwa siswa laki-laki dan perempuan menyebutkan bahwa guru dan petugas sekolah sebagai pelaku kekerasan. Sebagian besar siswa mengalami pem-bully-an di sekolah. Selain itu sebagian besar siswa mengalami kekerasan di sekolah. Kekerasan yang dilakukan oleh guru sebagai akibat dari penghinaan yang dilakukan oleh sesame guru atau tenaga kependidikan lainnya. Kekerasan psikologis diantara para pekerja, dalam hal ini adalah guru dan tenaga kependidikan berdampak pada kekerasan yang dilampiaskan kepada siswa atau sesama guru. ${ }^{16}$

Kekerasan di lingkungan sekolah juga disebabkan karena diskriminasi, baik diksriminasi gender, ras, kelompok ekonomi, sistem kepercayaan yang dianggap menyimpang, atau berbeda, sehingga menjadi isu yang digunakan untuk saling mengolok. ${ }^{17}$ Lebih lanjut bahwa stereotip sosial dan budaya ${ }^{18}$ memiliki dampak terhadap banyaknya korban kekerasan di lingkungan sekolah. Pemahaman akan orang lain, penting dilaksanakan agar saling menghargai dan menghormati orang lain. Gaya hidup yang melatar belakangi masing-masing indivisu juga menjadi daya ungkit munculknya kekerasan di lingkungann sekolah. ${ }^{19}$ Sebagai contoh siswa yang terbiasa membentak apalagi memukul akan terbiasa juga beperilaku demikian di lingkungan sekolah.

Kekerasan di lingkungan sebagai kelanggengan budaya kekerasan yang ada di sekolah yang belum diselesaikan dengan damai. Kekerasan di sekolah juga sebagai bentuk dari perlawanan dan alineasi serta frustasi. Kekerasan sebagai input masyarakat yang lebih luas daripada sistem persekolahan. ${ }^{20}$ Artinya tidak hanya mengenai persoalan pendidikan yang ada di sekolah tetapi permasalahan sosial yang lebih luas juga masuk ke dalam lingkungan sekolah. Nilai-nilai pribadi, antisosial pada remaja dan anak-anak terbentuk dari lingkungan keluarga, kebertetanggaan, nilai-nilai yang ada tersebut menavigasi sikap mentalnya ketika di lingkungan sekolah. ${ }^{21}$ Selain kehidupan luar sekolah, yang membentuk watak siswa adalah keikutsertaan dalam gang yang juga menavigasi perilaku negatif. ${ }^{22}$ Ketika siswa merasakan ketidakadilan dalam aturan sekolah atau perlakuan dari guru, mereka akan lebih mungkin untuk berpartisipasi dalam kekerasan. ${ }^{23}$ Oleh karena itu dukungan pihak lain penting juga ada, sehingga dicapai keseimbangan sikap mental siswa.

16 Diyah, N. C. M, Imron, A. (2016). "Kekerasan Dalam Pendidikan (Studi Fenomenologi Perilaku Kekerasan Di Panti Rehabilitasi Sosial Anak)". Paradigma. 4 (3) : h. 1-12.

17 Melanda, F. N., et al. (2017). "Poor Relationships and Physical Violence at School Are Associated With More Forms of Psychological Violence Among Brazilian Teachers: A Cross-Sectional Study". J Interpers Violence. h. 1-17.

18 Mooij, T. (2015). "School Indicators of Violence Experienced and Feeling Unsafe of Dutch LGB Versus Non-LGB Secondary Students and Staff, 2006-2010”. J Interpers Violence. 31 (20) : h. 3413-42.

19 Peguero, A. A., Jiang, X. (2016). "Backlash for Breaking Racial and Ethnic Breaking Stereotypes: Adolescent School Victimization Across Contexts". J Interpers Violence. 31 (6) : h. 1047-73.

${ }^{20}$ Horowitz, T.R., Kraus, V. (1987). "Violence at School: Situational Factors or Societal Input". Hisp J Behav Sci, 9 (2) : h. 183-205.

21 Bacchini, D., Affuso, G., Aquilar, S. (2015). "Multiple Forms and Settings of Exposure to Violence and Values: Unique and Interactive Relationships With Antisocial Behavior in Adolescence". J Interpers Violence. 30 (17) : h. 3065-88.

22 Souverein, F. A., Ward, C.L., Visser, I., Burton, P. (2015). "Serious, Violent Young Offenders in South Africa: Are They Life-Course Persistent Offenders?”. J Interpers Violence. 31 (10) : h. 1859-82.

23 James, K., Bunch, J., Clay-Warner J. (2015). "Perceived Injustice and School Violence: An Application of General Strain Theory". Youth Violence Juv Justice. 13 (2) : h. 169-89.

$$
147 \text { | S A S I Vol. } 26 \text { No.2, A pril - Juni } 2020
$$




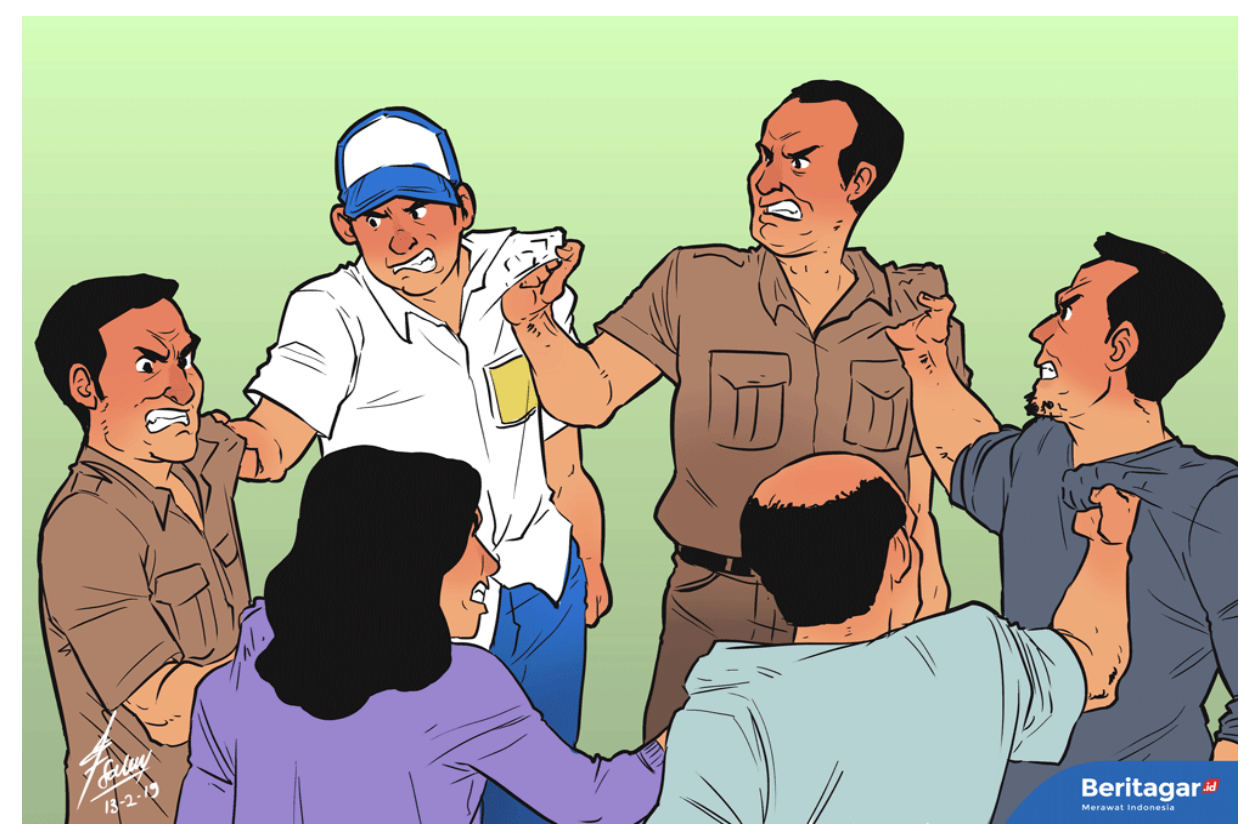

Relasi di lingkungan sekolah memang memungkinkan terjadinya gesekan dan konflik anatar pada civitas akademika sekolah. Hal tersebut dikarenakan berbagai faktor mulai dari individu masing-masing, beban kerja, budaya di sekolah, aturan-aturan kedisiplinan yang belum tersosialisasikan dengan sempurna. Namun demikian konflikkonflik tersebut harus diselesaikan sehingga tidak menimbulkan tindak kriminal dan menghambat proses belajar mengajar. Semua civitas akademika sekolah memiliki pemahaman bersama akan dampak dari kekerasan. Kesadaran akan dampak tindak kekerasan akan memunculkan rasa kebersamaan.

\section{Kekerasan Di Lingkungan Sekolah Dalam Kajian Hukum}

Desentralisasi pendidikan di bawah wewenang Kementerian Pendidikan dan Kebudayaan, terkadang muncul komunikasi yang lancar, Dinas Pendidikan Provinsi dan Kabupaten/Kota kurang memiliki wewenang dalam menyelesaikan persoalan kekerasan di lingkungan sekolah. Oleh karena itu keselarasan antara pemerintah pusat dan daerah dalam menyelesaikan kekerasan sangat penting.

Perlindungan hukum selain untuk peserta didik, juga untuk pendidik dan tenaga kependidikan, dalam permendikbud nomor 10 tahun 2017 dituliskan bahwa perlindungan merupakan upaya melindungi Pendidik dan Tenaga Kependidikan yang menghadapi permasalahan terkait pelaksanaan tugas. (2) Perlindungan sebagaimana dimaksud pada ayat (1) meliputi perlindungan: a. hukum; b. profesi; c. keselamatan dan kesehatan kerja; dan/atau d. hak atas kekayaan intelektual. Perlindungan hukum sebagaimana dimaksud pada ayat (2) huruf a mencakup perlindungan terhadap: a. tindak kekerasan; b. ancaman; c. perlakuan diskriminatif; d. intimidasi; dan/atau e. perlakuan tidak adil, dari pihak peserta didik, orang tua peserta didik, Masyarakat, birokrasi, dan/atau pihak lain yang terkait dengan pelaksanaan tugas sebagai Pendidik dan Tenaga Kependidikan. ${ }^{24}$ Dalam permendikbud nomor 10 tahun 2017, disebutkan secara detail tentang perlindungan bahwa pendidik dna tenaga kependidikan harus bebas dari tindakan kekerasan dalam

24 Permendikbud. Peraturan Menteri Pendidikan dan Kebudayaan Republik Indonesia nomor 10 Tahun 2017 tentang: Perlindungan bagi Pendidik dan Tenaga Kependidikan [Internet]. 2017. Available from: http://www.depkes.go.id/resources/download/laporan/kinerja/kinerja-kemenkes-2009-2011.pdf

$$
148 \text { | S A S I Vol. } 26 \text { No.2, April - Juni } 2020
$$


melaksanakan tugasnya.

Sebuah penelitian yuridis empiris, menunjukkan bahwa implementasi Permendikbud Nomor 82 Tahun 2015 dilaksanakan dengan program pencegahan dan program penanggulangan sebagai wujud perlindungan terhadap anak dari tindak pidana kekerasan. Implementasi ini bertujuan untuk mencegah dan menanggulangi tindak kekerasan di lingkungan satuan pedidikan terhadap peserta didik, dengan mengembangkan kerjasama pada orangtua/wali peserta didik, pendidik, tenaga kependidikan, satuan pendidikan, komite sekolah, masyarakat, pemerintah kabupaten/kota, pemerintah provinsi, dan pemerintah sesuai dengan kewenangannya. ${ }^{25}$ Lebih lanjut penelitian tersebut menungkap faktor- faktor penghambat implementasi Permendikbud Nomor 82 Tahun 2015 terdiri dari faktor aparat penegak hukum, yaitu terbatasnya SDM Tim Pencegahan dan Penanggulangan pada Satuan Pendidikan. Faktor masyarakat yaitu adanya keengganan siswa dan guru untuk menjadi saksi dalam proses penegakan hukum. Faktor budaya, yaitu adanya budaya individualisme dalam kehidupan masyarakat. ${ }^{26}$

\section{Optimalisasi Konselor Pendidikan/Guru BK}

Fungsi konseling merupakan materi sesitif dan serius. Konselor sekolah sering dihadapkan pada isu yang kompleks seperti percobaan bunuh diri, kekerasan anak, perilaku adiktif. Konselor sekolah merupakan pemimpin masyarakat sekolah, yang secara sistemik menghilangkan batasan dan hambatan bagi kesuksesan siswa. ${ }^{27}$ Dalam proses sejarah panjang kegiatan profesional persekolahan, konselor sekolah memiliki peran profesional dan sebagai komponen utama dalam profesi kolektif yang menyatukan dalam kegiatan konseling sekolah. Konselor sekolah berkolaborasi dengan system ekologi pendidikan dalam kegiatan profesionalnya. Konselor sekolah melakukan advokasi, sebagai pemimpin untuk membantu kesuksesan siswa.

Konselor sekolah menyediakan program konseling di tiga area kritis yakni akademik, personal atau sosial, dan karir. Kegiatan konseling personal atau sosial membantu siswa memiliki keseimbangan sikap sosial dan spiritual. Program konseling dilaksanakan secara terpadu dan komprehensif serta berkesinambungan. ${ }^{28}$ Program konseling di tiga area tersebut dimaksudkan untuk mencapai tujuan akan sumber daya manusia yang memiliki kecerdasan sosial dan emosional serta memiliki berkesejahteraan. Program konseling tersebut dirancang secara komprefensif menyasar aspek penting para siswa dan warga sekolah. Kesejahteraan warga sekolah meliputi adanya kesehatan mental dan fisik yang paripurna. Pembelajaran yang berbasis sosial dan emosional sehingga dapat meningkatkan prestasi belajar. Program yang dirancang oleh konselor sekolah berdasarkan pada teori atau petunjuk pelaksanaan dan berdasarkan data yang dibutuhkan untuk merancang program.

25 Permendikbud. Peraturan Menteri Pendidikan dan Kebudayaan Republik Indonesia nomor 10 Tahun 2017 tentang: Perlindungan bagi Pendidik dan Tenaga Kependidikan [Internet]. 2017. Available from: http://www.depkes.go.id/resources/download/laporan/kinerja/kinerja-kemenkes-2009-2011.pdf

${ }^{26}$ Nurani, A.S. (2018). "Implementasi Peraturan Menteri Pendidikan Dan Kebudayaan Nomor 82 Tahun 2015 Tentang Pencegahan Dan Penanggulangan Tindak Kekerasan Di Lingkungan Satuan Pendidikan". Fakultas Hukum Universitas Lampung. Vol. 53,

27 McMahon, G., Mason, C. C. M., Paisley, P. A. (2009). "School Counselor Educators as Educational Leaders Promoting Systemic Change". ASCA. 13 (2) : h. 116-24.

28 Camelford, K. G., Ebrahim, C. H. (2017). "Factors that affect implementation of a comprehensive school counseling program in secondary schools". Ideas Res you can use VISTAS 2017 Retrieved from http//www.counseling.org/knowledge-center/vistas, h. 1-10. 
Aspek yuridis tentang konselor di sekolah, dalam Undang-Undang nomor 20 tahun 2003 sejajar dengan guru, tutor, pamong. Pengakuan secara jelas dan kesejajaran posisi antara kualifikasi tenaga pendidikan memiliki makna bahwa setiap tenaga pendidik, termasuk Konselor, memiliki keunikan konteks dalam tugas, ekspektasi kinerja, dan setting layanan. ${ }^{29}$ Setting layanan konselor menyasar individu berbasis afektif, kognitif, dan psikomotorik. Setting layanan konseling juga berbasis pada kepemimpinan.

\begin{tabular}{|c|c|}
\hline Instrumen Hukum dan Kebijakan & $\begin{array}{c}\text { Isi Yang Terkait Dengan Guru } \\
\text { BK/Konselor di Sekolah }\end{array}$ \\
\hline $\begin{array}{l}\text { Undang-Undang nomor } 20 \text { Tahun } \\
2003 \text { Tentang Sistem Pendidikan } \\
\text { Nasional }\end{array}$ & $\begin{array}{l}\text { Guru BK/Konselor adalah bagian dari tenaga } \\
\text { pendidik dan memiliki kontribusi yang penting } \\
\text { terhadap keberhasilan peserta didik. }\end{array}$ \\
\hline $\begin{array}{l}\text { Peraturan Menteri } \quad \text { Pendidikan } \\
\text { Nasional No. } 22 \text { Tahun } 2006 \text { tentang } \\
\text { Standar Isi untuk Satuan Pendidikan } \\
\text { Dasar dan Menengah yang dirubah } \\
\text { menjadi Peraturan Menteri } \\
\text { Pendidikan dan Kebudayaan Nomor } \\
21 \text { tahun } 2016 \text { Tentang Standar Isi }\end{array}$ & $\begin{array}{l}\text { Layanan konseling berfokus pada } \\
\text { pengembangan individu, pengembangan } \\
\text { sosial, pekerjaan dan pendidikan. Layanan } \\
\text { konseling dapat dilaksanakan dalam kegiatan- } \\
\text { kegiatan di dalam/indoor dan di luar/outdoor } \\
\text { kelas yang terjadwal. Kegiatan konseling di } \\
\text { dalam/ indoor dijadwalkan } 2 \text { jam per kelas per } \\
\text { minggu }\end{array}$ \\
\hline $\begin{array}{lrr}\text { Peraturan } & \text { Menteri } & \text { Pendidikan } \\
\text { Nasional } & \text { No. } 27 & \text { Tahun 2008 } \\
\text { mengenai } & \text { Standar } & \text { Kualifikasi } \\
\text { Akademik dan Kompetensi Konselor }\end{array}$ & $\begin{array}{l}\text { Tugas-tugas Guru BK/Konselor adalah untuk } \\
\text { mendukung perkembangan pribadi dari para } \\
\text { pelajar sesuai dengan kebutuhan, bakat, minat, } \\
\text { dan keprbadian mereka, khususnya untuk } \\
\text { membantu peserta didik memahami dan } \\
\text { mengevaluas informasi dunia kerja dan } \\
\text { membuat pilihan-pilihan terkait pekerjaan. } \\
\text { Layanan dapat meliputi pengumpulan } \\
\text { informasi; orientasi; berbagi informasi; } \\
\text { rujukan, penempatan dalam sebuah program } \\
\text { pendidikan khusus; kunjungan rumah; } \\
\text { dukungan bidang studi khusus; konseling } \\
\text { berbasis kelompok dan personal, meditasi }\end{array}$ \\
\hline $\begin{array}{l}\text { Peraturan Pemerintah Nomor } 74 \\
\text { Tahun } 2008 \text { tentang Guru }\end{array}$ & $\begin{array}{l}\text { Pasal } 54 \text { ayat (6) menyatakan bahwa beban } \\
\text { kerja Guru BK atau Konselor adalah } \\
\text { mengampu bimbingan dan konseling paling } \\
\text { sedikit } 150 \text { (seratus lima puluh) peserta didik } \\
\text { per tahun per sekolah. Mereka juga berhak } \\
\text { mendapatkan tunjangan. Lebih lanjut Pasal } 54 \\
\text { ayat (6) menjelaskan layanan bimbingan dan } \\
\text { konseling adalah memberikan pengarahan dan } \\
\text { pengawasan kepada sekurang-kurangnya } 150 \\
\text { (seratus lima puluh) peserta didik melalui } \\
\text { latihan-latihan individual atau latihan-latihan } \\
\text { berbasis kelompok }\end{array}$ \\
\hline 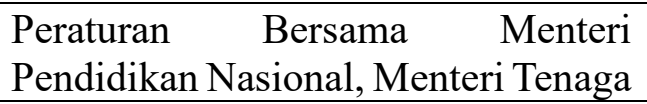 & $\begin{array}{l}\text { Pasal } 22 \text { ayat (5) menyatakan bahwa evaluasi } \\
\text { kinerja Guru BK/ Konselor mengukur }\end{array}$ \\
\hline
\end{tabular}

29 Kamaluddin, H. (2011). “Bimbingan dan Konseling Sekolah”. Jurnal Pendidik dan Kebudayaan”. 17 (4) : h. 447. 
Kerja dan Transmigrasi dan Kepala Badan Kepegawaian Negara Nomor 03/V/PB/2010 Nomor 14 Tahun 2010 tentang Petunjuk Pelaksanaan Jabatan Fungsional Guru dan Angka Kreditnya

Berdasarkan dasar-dasar hukum tersebut, Guru BK atau konselor di sekolah merupakan tenaga professional yang memiliki tugas pokok dan fungsi dalam mendukung terlaksananya proses pembelajaran yang efektif dan efisien. Guru BK/konselor sekolah merupakan tenaga profesional yang memiliki tugas preventif dan kuratif dalam melayani civitas akademika sekolah. Layanan konseling dirancang sedemikian rupa, dan wajib dipedomani di sekolah. Dengan adanya konselor sekolah diharapkan warga sekolah memiliki kematangan emosional, sosial, dan spiritual, sehingga tindak kekerasan di sekolah dapat ditanggulangi. Dasar-dasar hukum tersebut seharusnya mendukung intervensi dan keputusan yang dibuat diberbagai situasi siswa dan tindakan terapi. Kebijakan-kebijakan tersebut sebagai sumber informasi penting bagi masyarakat sekolah. Kebijakan tersebut digunakan untuk menyusun strategi preventif khususnya untuk situasi genting bagi siswa, menyediakan layanan pelatihan kepada guru dan staf, dan menyusun relasi kooperatif dengan agen-agen di masyarakat dan sekolah. ${ }^{30}$ Tugas seorang konselor di sekolah adalah melaksanakan intervensi substansi yang berdampak pada pendidikan siswa dan pengembangan diri, hal tersebut tentunya dengan menghilangkan dan mengelola gangguan-gangguan yang muncul termasuk tindak kekerasan.

\section{P E N U T U P}

Pemerintah pusat hingga daerah seharusnya memperhatikan dan menyusun aturan dan sarana sosialisasi yang terukur, sehingga peraturan tersebut bisa dipedomani seluruh masyarakat sekolah. Ilmuwan bidang manajemen dan administrasi pendidikan penting untuk menyisipkan dan mengembangkan teori dan praktik, sehingga pemahaman para pendidik dan tenaga kependidikan akan penanggulangan kekerasan dapat meningkat, sehingga pendidik dan tenaga kependidikan dapat berkomunikasi ke segala arah dalam preventif kekerasan di sekolah. Pemerintah pusat berkoordinasi, secara bersama-sama menyusun payung hukum yang diketahui dan dipahami secara konvergensi.

\section{DAFTAR PUSTAKA}

\section{Buku}

[1] Mehta, D. (2009). Educational administration. New Delhi: A.P.H. Pub. Corp.

\section{Jurnal}

[2] Borders, L. D., Drury, S. M. (1992). "Comprehensive School Counseling Programs: A Review for Policymakers and Practitioners”. J Couns Dev. 70 (4) :h. 487-98.

[3] Bacchini, D., Affuso, G., Aquilar, S. (2015). "Multiple Forms and Settings of Exposure to Violence and Values: Unique and Interactive Relationships With

30 Borders, L. D., Drury, S. M. (1992). “Comprehensive School Counseling Programs: A Review for Policymakers and Practitioners”. J Couns Dev. 70 (4) :h. 487-98. 
Antisocial Behavior in Adolescence”. J Interpers Violence. 30 (17) :306-588.

[4] Bezem, J. Heinen, D. Reis, R. Buitendijk, S. E., Numans, M. E., Kocken, P. L. (2017). "Improving access to school health services as perceived by school professionals". BMC Health Serv Res. 17 (743) : 1-8.

[5] Diyah, N. C. M., Imron, A. (2016). "Kekerasan Dalam Pendidikan (Studi Fenomenologi Perilaku Kekerasan Di Panti Rehabilitasi Sosial Anak)". Paradigma. $4(3): 1-12$.

[6] Horowitz, T. R., Kraus, V. (1987). "Violence at School: Situational Factors or Societal Input". Hisp J Behav Sci, 9 (2) : 183-205.

[7] Hattu, J. "Kebijakan Hukum Pidana Dalam Penanggulangan Kejahatan Anak". SASI. $20(2): 47-52$.

[8] James, K., Bunch, J., Clay-Warner, J. (2015). "Perceived Injustice and School Violence: An Application of General Strain Theory". Youth Violence Juv Justice. 13 (2) : 169-89.

[9] Kamaluddin, H. (2011). "Bimbingan dan Konseling Sekolah". J Pendidik dan Kebudayaan. 17 (4) : 447.

[10] Latuny, M. (2012). "Peran Ganda Perempuan Dalam Keluarga”. SASI. 18 (1) : 1320.

[11] McMahon, G., Mason, C. C. M., Paisley, P. A. (2009). "School Counselor Educators as Educational Leaders Promoting Systemic Change”. ASCA. 13 (2) : 116-24.

[12] Mooij, T. (2015). "School Indicators of Violence Experienced and Feeling Unsafe of Dutch LGB Versus Non-LGB Secondary Students and Staff, 2006-2010”. J Interpers Violence. 31 (20) : 3413-42.

[13] Melanda, F. N, et al. (2017). "Poor Relationships and Physical Violence at School Are Associated With More Forms of Psychological Violence Among Brazilian Teachers: A Cross-Sectional Study". J Interpers Violence. 1-17.

[14] Nofziger, S. (2009). "Deviant Lifestyles and Violent Victimization at School. J Interpers Violence”. 24 (9) : 1494-517.

[15] Nurani, A. S. (2018). "Implementasi Peraturan Menteri Pendidikan Dan Kebudayaan Nomor 82 Tahun 2015 Tentang Pencegahan Dan Penanggulangan Tindak Kekerasan Di Lingkungan Satuan Pendidikan”. Fakultas Hukum Universitas Lampung. Vol. 53.

[16] Pasalbessy, J. D. (2010). "Dampak Tindak Kekerasan Terhadap Perempuan Dan Anak Serta Solusinya". SASI.16 (3) : 8-13.

[17] Peguero, A. A., Jiang, X. (2016). "Backlash for Breaking Racial and Ethnic Breaking Stereotypes: Adolescent School Victimization Across Contexts". J Interpers Violence. 31 (6) : 1047-73.

[18] Rumapea, R. A. (2019). "Pertanggungjawaban Hukum Pejabat Pembina Kepegawaian dan Pejabat yang Berwenang atas Kesalahan dalam Penjatuhan Hukuman Disiplin Pegawai Negeri Sipil”. SASI. 25 (28) : 133-45.

[19] Souverein, F. A., Ward, C. L., Visser, I., Burton, P. S. (2015). "Violent Young Offenders in South Africa: Are They Life-Course Persistent Offenders?". J Interpers Violence. 31 (10) : 185-982.

\section{Online/World Wide Web}

[20] Republika. "Kasus Kekerasan Terhadap Guru Kesalahan Sistemis" | Republika Online [Internet]. Republika. 2019 [cited 2019 Dec 29]. Available from: https://republika.co.id/berita/pmuwyp291/kasus-kekerasan-terhadap-gurukesalahan-sistemis

[21] Republika. Pendidikan Karakter Harus Diperkuat di Sekolah | Republika Online 
[Internet]. Republika. 2018 [cited 2019 Dec 29]. Available from: https://republika.co.id/berita/p3kaqz284/pendidikan-karakter-harus-diperkuat-disekolah

[22] [Republika. Kekerasan Jadi Tantangan Pendidikan di Indonesia | Republika Online [Internet]. Republika. 2017 [cited 2019 Dec 29]. p. 1. Available from: https://republika.co.id/berita/oz3e86368/kekerasan-jadi-tantangan-pendidikan-diindonesia

[23] Liputan Khusus Koran Sindo. Belum Bayar SPP, Bocah 10 Tahun Dihukum Push-up 100 Kali [Internet]. Sindo News. 2019 [cited 2019 Dec 29]. p. 1. Available from: https://metro.sindonews.com/read/1374283/170/belum-bayar-spp-bocah-10-tahundihukum-push-up-100-kali-1548685354

[24] Liputan Khusus Koran Sindo. Diduga Aniaya Murid, Guru Sekolah Internasional Dilaporkan ke... [Internet]. Sindo News. 2019 [cited 2019 Dec 29]. p. 1. Available from: https://metro.sindonews.com/read/1400581/170/diduga-aniaya-murid-gurusekolah-internasional-dilaporkan-ke-polisi-1556722061

[25] Liputan Khusus Koran Sindo. Di-bully Senior, 13 Siswi di Tangerang Selatan Ditampar hingga Dipaksa... [Internet]. Sindo News. 2019 [cited 2019 Dec 29]. p. 1. Available from: https://metro.sindonews.com/read/1426171/170/di-bully-senior-13siswi-di-tangsel-ditampar-hingga-dipaksa-berduel-1564733037

[26] Republika. KPAI Dorong Kemendikbud Tingkatkan Keamanan di Sekolah | Republika Online [Internet]. Republika. 2019 [cited 2019 Dec 29]. p. 1. Available from: https://republika.co.id/berita/q35byn368/kpai-dorong-kemendikbudtingkatkan-keamanan-di-sekolah

[27] Republika. Tindak Kekerasan di Sekolah dan Efekivitas Permendikbud 82 | Republika Online [Internet]. Republika. 2019 [cited 2019 Dec 29]. p. 1. Available from: https://republika.co.id/berita/qlizh6349/tindak-kekerasan-di-sekolah-danefekivitas-permendikbud-82 